\title{
СЮЖЕТЫ НАСКАЛЬНОГО ИСКУССТВА ЦЕНТРАЛЬНОЙ АЗИИ КАК МАРКЕРЫ МИГРАЦИОННЫХ ПУТЕЙ
}

\author{
(С) 2019 г. И.Н. Швец
}

\begin{abstract}
Статья посвящена одному из сюжетов наскального искусства Центральной Азии, отнесенного нами условно к категории знаков-символов. Богатейший материал гравюр быков в петроглифах Сауыскандыка (Южный Казахстан) демонстрирует не только многообразие декора на туловище животных, но также наличие знаков в форме круга, выполненных в рельефно-контррельефной технике. Данные знаки могут быть не только хроноиндикаторами сюжетов наскального искусства эпохи ранней бронзы, но и являются маркерами продвижения традиций окуневского искусства в юго-западном направлении. Петроглифы и росписи как памятники изобразительного искусства, к тому же монументального, могут в образах и знаках, возможно, в иконографических кодах маркировать и «окаменять» пути миграций и контактов древних людей. Поиск путей этих миграций и контактов выглядит для нас более убедительным не только в определении идентичных сюжетов на удаленных территориях, но и в выявлении общих специфических знаков-кодов и контекстов изображенного.

Ключевые слова: археология, Центральная Азия, Южный Казахстан, Сауыскандык, изобразительное искусство, петроглифы, знак, символ, код, окуневская культура, документация полевых исследований
\end{abstract}

\section{Введение}

С середины XX века ученые уделяют пристальное внимание памятникам изобразительного искусства Центральной Азии. С течением времени менялись аспекты и задачи в изучении этих археологических объектов. При всеобщей любви к публикациям петроглифов во всевозможных археологических и публицистических изданиях, остаются проблемы акцептации данного археологического памятника как надежного исторического источника. При критическом рассмотрении данных объектов самым большим минусом остается их довольно относительная датировка. Необходимо отметить, что сегодня наряду с патиной и палимпсестами, стилем и изображением хорошо датируемых деталей, будь то транспорт или оружие, более надежными и акцептируемыми хронологическими индикаторами в случае с петроглифами являются каменные плиты с рисунками, найденные в погребенниях. Использование именно петроглифов в освещении проблемы миграционных путей в архаичные эпохи, в решении которой участвуют представители не только гуманитарных, но и точных наук, должно вызвать волну недоумения. Как это возможно? Какова степень достовер- 
ности этих утверждений? Возможно, ответ на этот вопрос заключается в специфике этого археологического источника. Петроглифы и росписи как памятники изобразительного искусства, к тому же монументального, могут в образах и знаках, возможно, в иконографических кодах маркировать и «окаменять» пути миграций и контактов древних людей. Причем если это были контакты, то они должны были быть довольно интенсивными, так как была перенята система изобразительных образов/знаков/кодов определенной культуры. Она повторялась и воспроизводилась, скорее всего, на протяжении нескольких генераций, в географическом удалении от первоначального очага как один их элементов культурной памяти. Выявление возможных контактов населения Центральной Азии в архаические эпохи по петроглифам и росписям могли бы стать еще одним звеном в определении миграционных волн населения на этой территории. Поиск путей этих миграций и контактов выглядит для нас более убедительным не только в определении идентичных сюжетов на удаленных территориях, но и в выявлении общих специфических знаков/кодов и контекстов изображенного.

Характеристика и анализ материала

Исследование наскального искусства становится все более специальным: от простого описания и определения относительной хронологии местонахождений петроглифов до конкретного анализа собранного материала. Появились работы, изучающие отдельные образы наскального искуства - транспорт [Новоженов, 1994; Есин, 2012], ряженные [Швец, 1998; 1999], солнцеголовые, тамги [Рогожинский, 2016], религи- озные символы и надписи [Рогожинский, 2018; Bemmann, König, 1994; Fussman, König, 1997]. Опыт изучения наскального искусства последних лет показывает, что наиболее успешным в определении миграционных путей и контактов архаических эпох являются как раз сюжеты, иллюстрирующие технологии, надписи, тамги, религиозные символы или специфические символы/знаки/коды, точное определение которых для нас не всегда ясно, но их значимость для архаичных культур очевидна в силу их повторяемости. Следуя высказыванию Й. Ассманна, именно повторяемость знаков и элементов должна способствовать идентификации культуры через узнаваемые образы и элементы [Assmann, 2000, с. 18]. В нашем случае повторение на скалах специфических знаков представляется не грубым копированием понравившегося образа путем случайного контакта, а его повторением в силу важности и идентификации с ним.

Благодаря интенсивному изучению местонахождений наскального искусства Казахстана и Центральной Азии с начала 90-х годов прошлого века, стало возможным накопление огромного материала. Качественные копии, но, прежде всего, высокопрофессиональные фотографии позволили выявить ряд сюжетов наскального искусства, обогативших наши знания по колесному транспорту, тамгам и тюркским рисункам степной полосы Центральной Азии.

В ходе двухлетней исследовательской компании при поддержке немецкого фонда имени Герды Хенкель (Gerda Henkel Stiftung, Deutschland) было изучено и документировано местонахождение Сауыскандык хребта Каратау (Южный Казахстан) (рис. $1 ; 2)$, что позволило выявить ряд 
Швец И.Н. Сюжеты наскального искусства Центральной Азии как маркеры...

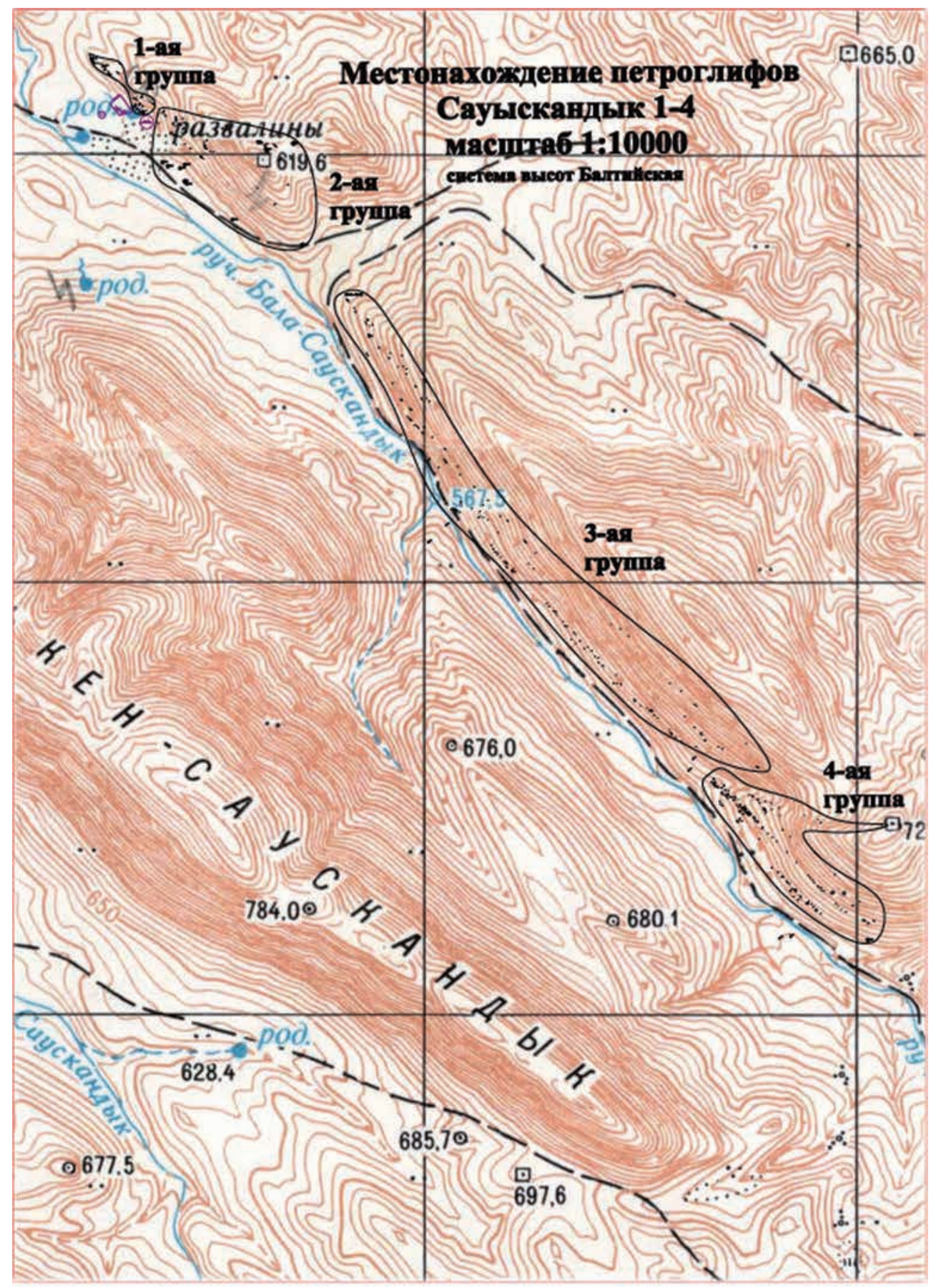

Рис. 1. Карта расположения групп петроглифов Сауыскандык-1-4. Исполнители: Бухарин Д., Муратиди К.

Fig. 1. Petroglyphs of the Sauyskandyk, groups 1-4. Executors: Bucharin D., Muratidi K. 


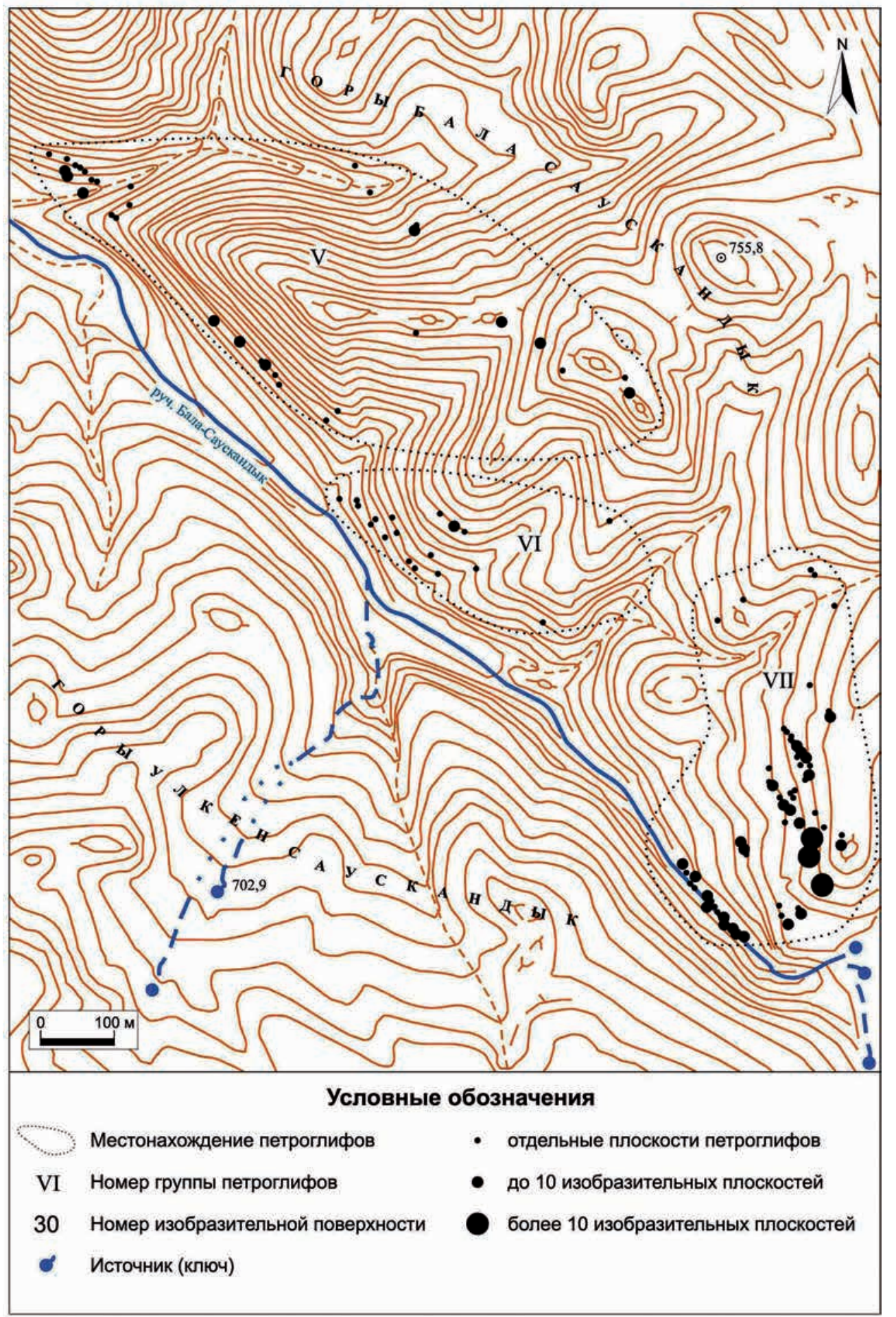

Рис. 2. Карта расположения групп петроглифов Сауыскандык-5-7. Исполнители: Бухарин Д., Муратиди К.

Fig. 2. Petroglyphs of the Sauyskandyk, groups 5-7. Executors: Bucharin D., Muratidi K. 
Швец И.Н. Сюжеты наскального искусства Центральной Азии как маркеры...

сюжетов наскального искусства Южного Казахстана, свидетельствующих о контактах населения данного региона в эпоху ранней и развитой бронзы с населением Сибири [Швец, 2011; Швец и др. 2008а; 2008б]. С данными выводами, представленными на ряде конференций, согласились специалисты по окуневскому искусству. Так Ю. Есин подтверждает стилистическую близость тягловых животных и конструктивное сходство повозок в петроглифах Сауыскандыка с подобными сюжетами на памятниках окуневской культуры [Есин, 2012, с. 37]. Изображения быков являются типичными для всех местонахождений Казахстана. Они показаны как схематично, так и с особой детализацией. В петроглифах гор Бала-Сауыскандык изображение быка демонстрирует особое многообразие выбивки и вариаций в изображении таких деталей как рога, хвост, корпус. Бык изображен статичным, запряженным в облегченную двухколесную повозку и четырехколесную телегу (?). Фигуры быка встречаются в композициях с ряжеными, роженицами, «coitus»сюжетами.

Большинство изображений быков в петроглифах гор БалаСауыскандык датируется, вероятнее всего, эпохой энеолита-ранней бронзы. Именно с этим временным пластом связаны наиболее тщательно исполненные изображения данных животных. Все они имеют массивный корпус и мощные серповидные или же выполненные в виде кольца, направленные вперед, а также волнообразные рога. Хвосты животных имеют на конце листовидную форму или форму шара, а также изображены в виде полсы. Корпус быка чаще показан сплошной выбивкой, встречается также скелетная/ажурная техни- ка, а также элементы барельефа. Бык показан одиночно стоящим, в парах, в упряжке. Фигура животного часто встречается в сценах с участием антропоморфного сюжета, выполненного реалистично, или так называемого ряженного, будь то сцена охоты или перекочевки, иллюстрация мифа, «coitus-сцена».

Среди петроглифов Сауыскандыка имеются редкие изображения упряжных быков с небольшими колечками на кончике морды, предназначенными для крепления ремней управления. Через такие кольца в носу тяглового быка пропускались ремни или веревка, с помощью которых достаточно эффективно осуществляли контроль и управление животными. Во многих случаях хорошо видно, что ремни-вожжи примыкают к кончикам морды животных: в СаймалыТаше (Кыргызстан) [Шер, 1980, c. 195-196], Байконуре (Центральный Казахстан) [Новоженов, 2002, с. 95], Ешкиольмесе (Жетысу) [Марьяшев, Горячев, 2002, с. 148]. Такой способ управления с помощью кольца в носу многократно запечатлен среди окуневских изображений быков в Южной Сибири [Leontiev, Kapelko, 2002, abb. 24].

Быков из урочища Сауыскандык сближает с саймалы-ташскими также и трактовка кистей хвоста в виде треугольной геометрической фигуры, и присутствие в композиции хвостатых ряженых персонажей, а также малые габариты колес повозок. Сходства на этом кончаются, сауыскандыкские образцы по сравнению с саймалыташскими более реалистичны, динамичны и в ряде случаев отмечены солярными символами-кольцами, круглыми точками, решетчатыми знаками и др. Репрезентативную группу изображений быков из Сауыскандыка 
и Жетысу составляют те, у которых корпусы разрисованы различными геометрическими узорами, «клетками», кругами, точками, волнистыми и зигзагообразными линиями, расположенными как вертикально, так и горизонтально. В декорировании подобными «узорами» туловища быков пока не улавливается какая-либо система или числовая характеристика, поэтому каждая разрисованная фигура отличается своей индивидуальностью и неповторимостью. Нет хронологического разрыва и между «ажурными» и обычными фигурами быков; они чаще встречаются вместе и поэтому такой способ оформления корпуса животных нужно рассматривать, видимо, с точки зрения религиозных воззрений древних людей и как семантическое явление [Shvets и др., 2008].

Природа такого рода маркировок неопределенно-геометрическими узорами изображений животных в эпоху бронзы не вполне понятна. Они могут быть квалифицированы как обычный декоративный элемент или, в ряде случаев, как попытка древнего мастера необычным художественным приемом передать особенности естественной окраски шерсти животных [Shvets и др., 2008]. В петроглифах Саяно-Алтайской провинции, включая Монгольский Алтай, фигуры быка с разрисованным туловищем встречаются реже, чем в северо-тяньшанской провинции. Изображения быка/яка, корпус которого разделен вертикальными линиями, присутствуют в памятниках Северной Монголии [Новгородова, 1989, с. 317]. Изображения животных, особенно оленей и верблюдов с заштрихованным телом, встречаются и в раннем железном веке, что свидетельствует о популярности данной изобразительной традиции.

\section{Стилистические} параллели изображениям быков Сауыскандыка в памятниках окуневской культуры среди петроглифов эпохи бронзы Саймалы-Таш, а также техника, патина и сохранность рисунков позволяют датировать данный зооморфный образ Сауыскандыка в большей части концом III - началом II тыс. до н.э.

Изображения быков были связаны, скорее всего, с его экономической и ритуальной ролью у племен данной эпохи. Для более поздних периодов истории региона это животное теряет свое былое значение. Это связано и со сменой хозяйственной деятельности, и с исчезновением дикого быка в степях Евразии - в прошлом одной из крупнейших охотничьих добыч, основным тягловым животным, и соответственное его смещение в культах и верованиях населения. Исчезновение дикого быка началось в большей части Евразии в эпоху бронзы, в некоторых районах Алтая ограниченное количество диких быков сохранилось вплоть до XVIII в. Кости одомашненного быка фиксируются в небольшом количестве почти на всех поселениях эпохи ранней и развитой бронзы Казахстана [Кадырбаев, Марьяшев, 1977, с. 172]. Подобная ситуация характерна также для неолита и эпохи бронзы Средней Азии, Кавказа и Украины. В I тыс. до н.э. в остеологическом материале Узбекистана они полностью исчезают [Хужаназаров, 1995 , с. 66-67].

Сравнительный анализ 3о0морфных образов культур эпохи бронзы и раннего железного века свидетельствует об их трансформации и подчинении идеологии номадичества. Показательным моментом для иллюстрации данного факта, по мнению Ю.А. Мотова, является олицетворение образа быка у «пазырыкцев» уже 
Швец И.Н. Сюжеты наскального искусства Центральной Азии как маркеры...

в качестве «чужого» в кочевом стаде. Отмечаются следы применения быков в качестве тягловой силы и сырьевой основы в изготовлении изделий, но он полностью отсутствует в круге зооморфных образов пазырыкского искусства [Мотов, 2007, с. 62].

Интерес представляют несколько изображений телег в бычьих упряжках из Сауыскандыка с устойчивым набором технических элементов и признаков: с четырьмя маленькими колесами на углах прямоугольных платформ, в парных бычьих упряжках, где животные показаны в основном с разрисованными туловищами и располагаются по сторонам дышла друг над другом. Эти телеги демонстрируют также особую конструкцию сложносоставного «рогатинообразного» дышла: основание прикрепляется с помощью рогатки к передней части транспорта, а другой конец - к поперечной перекладине - ярму. Телеги точно такой же конструкции известны среди петроглифов Сармишсая (Узбекистан) [Хужаназаров, 1995, с. 63]

Многочисленные гравюры быков в петроглифах Сауыскандыка, опубликованные в работе 3. Самашева, С. Мургабаева М. Елеуова [Самашев и др., 2014, с. 148-164], демонстрируют многообразие приемов древнего художника в изображении этого животного. Наличие необычного декора на теле быков Сауыскандыка позволяет видеть в этом природное разнообразие цвета шерсти или же окрашивание (?), контрастное выстригание (?) шерсти у ритуального/ жертвенного животного. Не- обходимо отметить, что подобным образом изображенны и верблюды в петроглифах Сауыскандыка. Данный факт, а также присутствие декора на туловищах быков, запряженных в повозки, плуг (?), т.е. показанных в бытовых сценах, вызывает ряд вопросов к чисто ритуальному предназначению данного рисунка на туловище животных.

Наряду с рисунками в виде полос и геометрических фигур, на туловище быков изображены повторяющиеся символы в форме круга. Лаконичность данного изображения, сочетание в его исполнении одновременно техник рельефа и контрре-

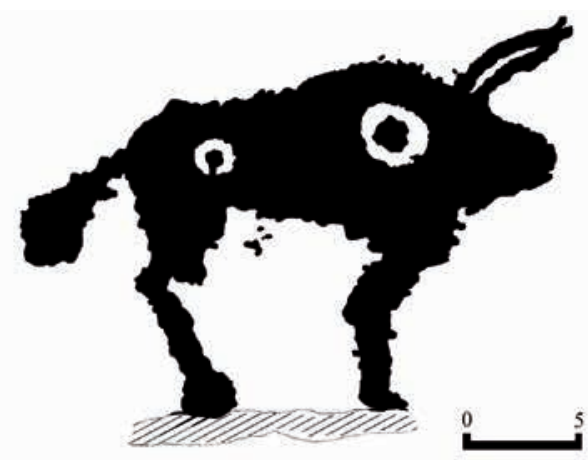

I

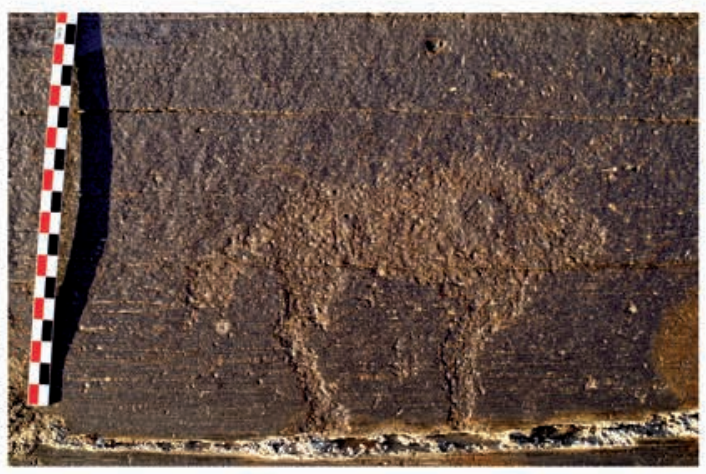

2

Рис. 3. Изображение быка со знаком на туловищее. Сауыскандык. 1 - (по: [Самашев и др., 2014, фото 3087); 2 - фото И.Н. Швец

Fig. 3. Bull with a sign on the body. Sauyskandyk. 1-(by: [Samashev et al., 2014, photo 308]); 2 - Photo by Shvets I. 
льефа делает его присутствие на теле животного «знаковым», не случайным. Его исполнение в отличие от вышеописанных разнообразных декоров на шерсти быков всегда остается одинаковым и предполагает определенную трудность и тщательность в исполнении (рис. 3).

Т. Рябкова, исследовавшая один из подобных знаков в искусстве раннего железного века, определяла его как «точка, переданная контррельефным углублением или рельефным
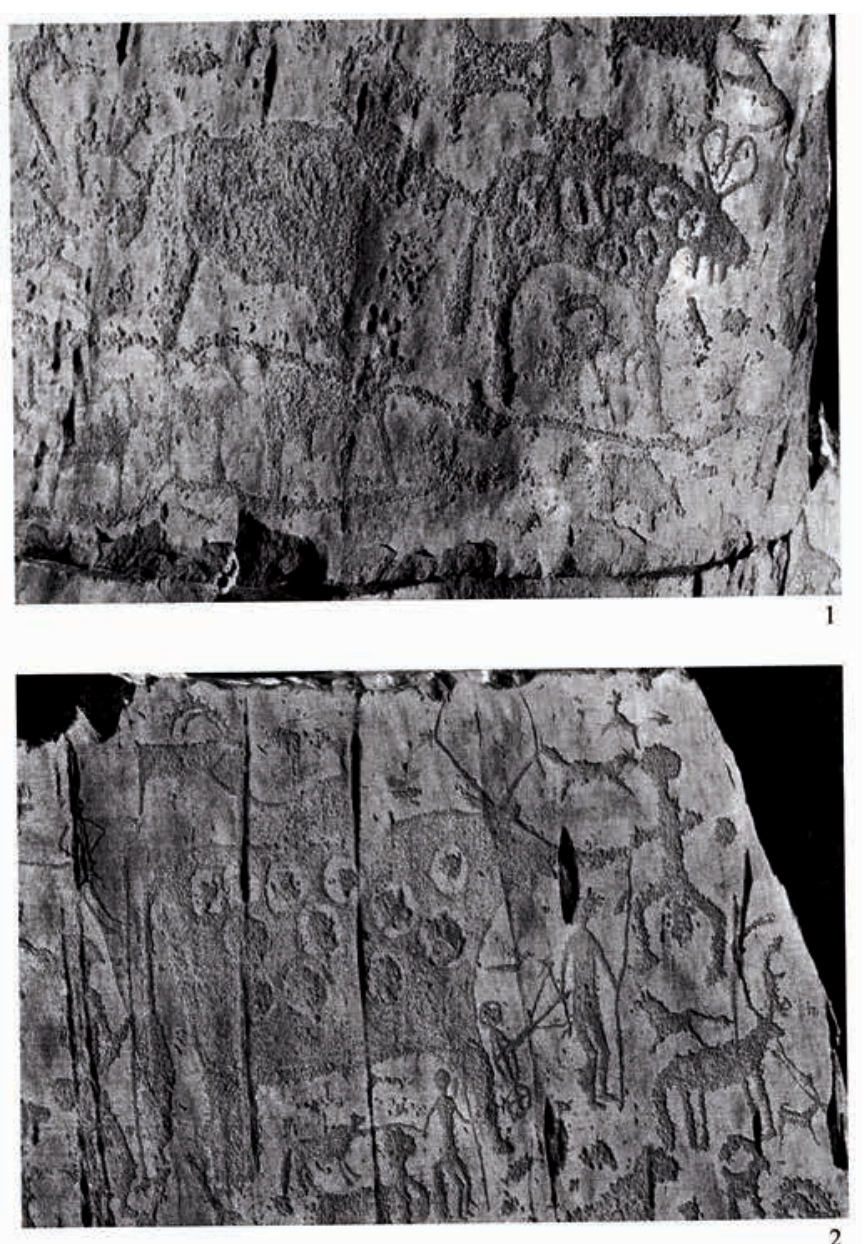

Рис. 4. Изображение быков со знаками на туловище. 1-2 - Алтай (по: [Дэвлет Е., Дэвлет М.А., 2010, pomo 3.6; 2.19])

Fig. 4. The bulls with the signs on bodies. 1-2-Altay (by: [Devlet E., Devlet M., 2010, photo. 3.6; 2.19]) кружком и вписанная в ромб» [Рябкова, 2011, с. 105]. По ее мнению, данный знак был особенно популярен в окуневской культуре и присутствует практически на всех окуневских изваяниях.

Более простым знаком, выполненным не только на окуневских стелах, но и на многочисленных фигурах быков в петроглифах Алтая [Дэвлет Е., Дэвлет М., 2010, с. 144, рис. 292] (рис. 4), Жетысу [Байпаков, Марьяшев, 2004, фото 88] (рис. 5) и

Южного Казахстана (рис. 6) являются круги с точкой внутри и рельфным валиком по окружности. 3. Самашев, С. Мургабаев и М. Елеуов назвали этот знак «рельефным кольцом» [Самашев и др., 2014, фото 289].

Стиль изображения быков и зооантропоморфных («ряженных») образов в петроглифах Байконура [Новоженов, 2002] делают наличие знаковточек в рельефноконтррельефной технике на этом местонахождении вполне ожидаемым. Но сохранность петроглифов Байконура настолько плоха, что возможны трудности в идентификации этих знаков на туловище быков. При этом фиксация данного знака-символа возможна только на качественных фотографиях, черно-белые прорисовки и микалентные копии не пол- 
Швец И.Н. Сюжеты наскального искусства Центральной Азии как маркеры...

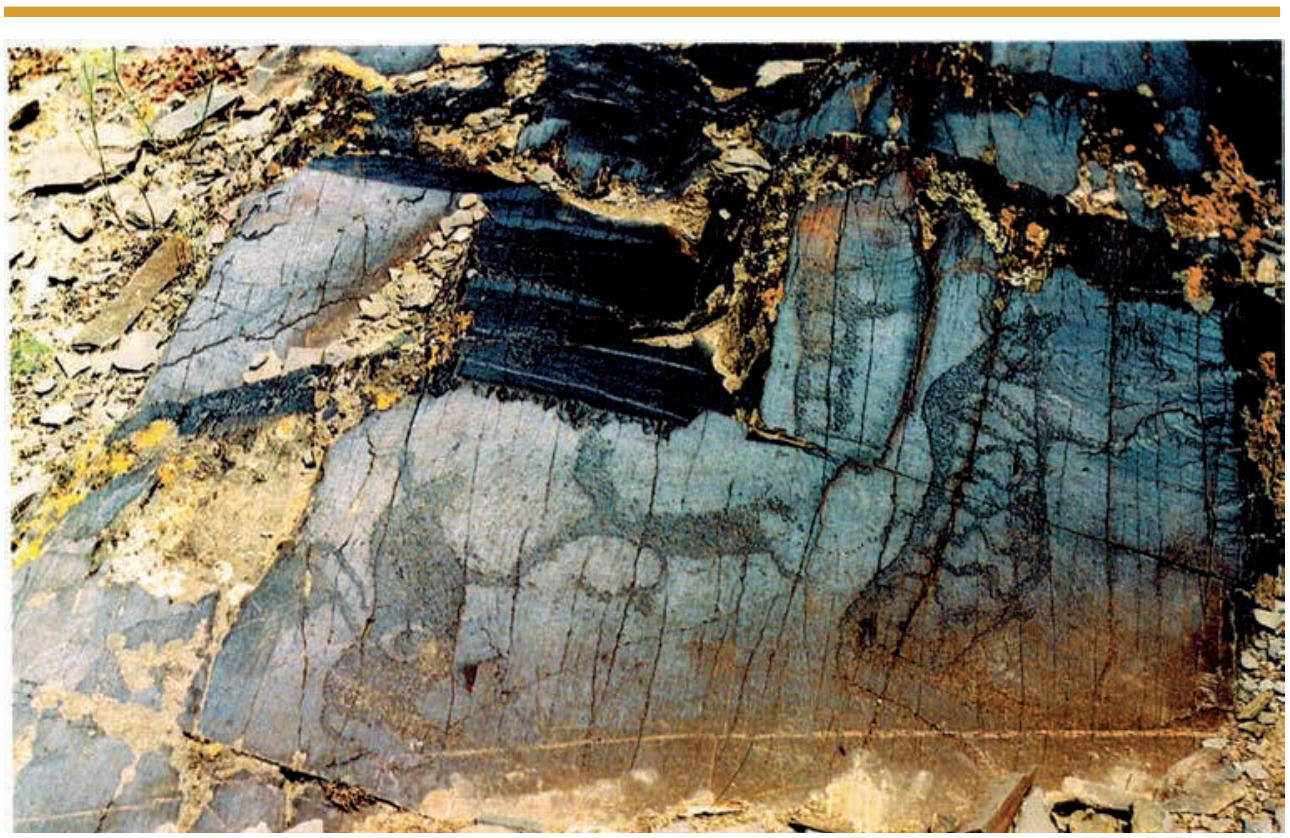

Рис. 5. Изображение быка со знаком на туловище, Кулжсабасы (по: [Байпаков, Марьяшев, 2004, фото 88])

Fig. 5. Bull with a sign on the body, Kuljabasy (by: [Baipakov, Maryashev, 2004, photo 88])

ностью отражают технику рельефа и контррельефа, используемую при выбивке данных знаков/символов/ кодов. Здесь мы сталкиваемся с проблемой выявления подобных сюжетов (выделено автором - прим. ред.) и с необходимостью нового взгляда на репертуар петроглифов при помощи качественной фотосъемки.

Данные знаки могут быть не только хроноиндикаторами сюжетов наскального искусства эпохи ранней бронзы, но и являться маркерами продвижения традиций окуневского искусства в юго-западном направлении, так как очаг данного знакового символизма, будь то круг в виде рельефного валика с точкой внутри или вписанный рельефный кружок в ромб, находился на Енисее. Подобное утихание одной из монументальнохудожественных традиций эпохи раннего железа с востока на запад, связанных с установкой оленных камней, а также «ослабление» погребальной традиции - уменьшение количества жертвенных лошадей в эпоху раннего железа с востока на запад отмечают в своей работе А.З. Бейсенов и соавторы [Бейсенов и др., 2017, с. 46].

\section{Заключение}

По мнению ряда исследователей, «простые» в исполнении символы обладают бо́льшей культурносмысловой емкостью, чем сложные. В. Тэрнер предполагал, что простая форма, представляющая определенный цвет, очертания, может буквально и метафизически связать большой ряд явлений, понятий, быть изначально многознаковой. Сложная форма (т.е. сочетание цветов, стилей, форм, материала и др.) уже проведена исполнителем через множество контрастов (композиция, техника, цветовая гамма и др.) и это сужает, ограничивает, конкретизирует ее миссию [Тэрнер, 1983, с. 39]. В силу этого основные 


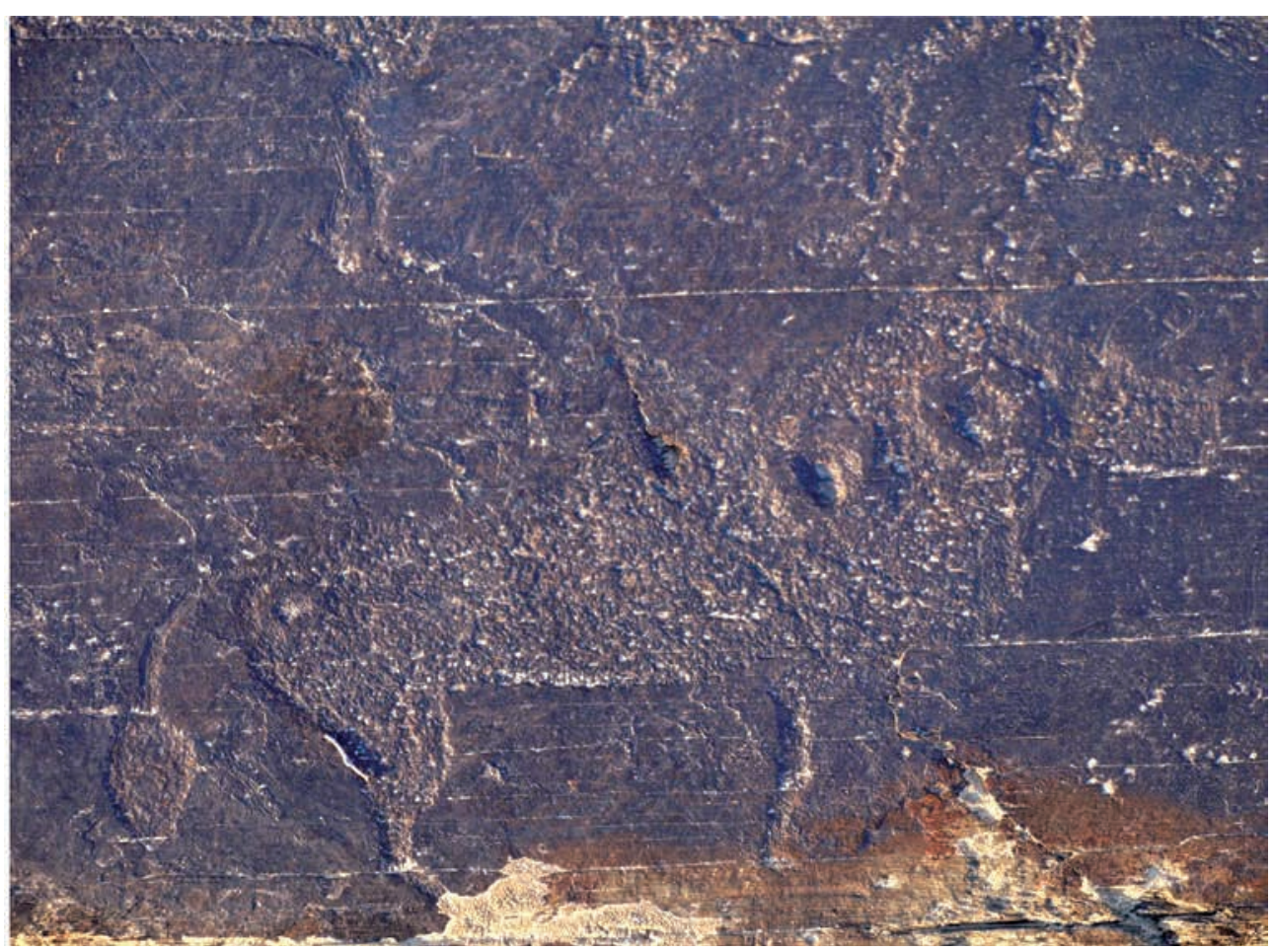

Рис. 6. Изображение быка со знаками на туловище, Сауыскандык (nо: [Самамев и др., 2014, фото 289])

Fig. 6. Bull with a signs on the body, Sauyskandyk (by: [Samashev et al., 2014, photo 289])

религиозные символические формы - крест, лотос, свастика, хотя и сравнительно просты, обладают глубокой смысловой нагрузкой и образуют целые типологические ряды. Исходя из данного определения, В. Тернер выводит понятия локального и универсального ритуала. Первый отличается сложностью, структурированностью, второй - простотой и широтой его миссии.

Существует определенная иерархия знаков, представленных в наскальном искусстве; знак-индекс ассоциируется с обозначаемым объектом в силу действительно существующей между ними в природе связи, иконический знак предполагает фактическое сходство; знак-символ не обнаруживает никакой природно- обусловленной связи между собой и объектом, знак-символ является знаком объекта на основании соглашения [Семенов, 1998, с. 50]. У некоторых символических форм в наскальном искусстве есть ясность и определенность, четкая связь с изображенными предметами - изображение стопы, руки, копыта, креста. Другие остаются неясными для нас, непостижимыми и переходят в ранг «загадочной картинки».

Со времен палеолита люди обладали способностью обращать в символы свое окружение. Наличие символики в искусстве разных эпох свидетельствует о преемственности и «успешности» этой художественной системы в отражении материального и духовного мира древним челове- 
Швец И.Н. Сюжеты наскального искусства Центральной Азии как маркеры...

ком. По мнению А. 3. Бейсенова и соавторов, в эпоху раннего железа: «орнаментальные композиции - своеобразные знаки-символы, имели такое же распространение как и изображения, выполненные в зверином стиле» [Бейсенов и др., 2017, с. 43].

Простота формы представленного к рассмотрению знака, изображенного на туловищах быков эпохи ранней бронзы, подразумевает его универсальность и широту применения. Его связь с туловищем быка могла бы трактоваться как в мифоритуальном контексте - оберег, знак жертвоприношения («отмеченность»), так и в профанном назначении этих символов - знак собственности, подвид и масть животного. Анализ и интерпретация знакового комлекса в петроглифах Центральной Азии ставит перед исследователями задачу более тщательного подхода к фиксации и документированию изобразительного материала. Подобный пласт петроглифов возможно выявить только при помощи высококачественных фотографий петроглифов, фиксирующих комбинацию рельефной и контррельефной выбивки.

\section{ЛИТЕРАТУРА}

1. Байпаков К.М., Марьямев А.Н. Петроглифы в горах Кульжабасы. Алматы: "Print-S“, 2004. 22 с. 88 ил.

2. Бейсенов А.З., Джумабекова Г.С., Базарбаева Г.А., Дуйсенбай Д.Б., Ахияров И.К. Вихревые композиции в искусстве саков Центрального Казахстана // Археологія і давня історія України. 2017. Вип. 2 (23). С. 40-58.

3. Дэвлет Е.Г., Дэвлет М.А. Сокровища наскального искусства Северной и Центральной Азии. М.: ИА РАН, 2011. 379 с.

4. Есин Ю.Н. Древняя история и традиционная культура. Древнейшие изображения повозок минусинской котловины. // Научное обозрение Саяно Алтая. 2012. № 1 (3). C. 14-47.

5. Кадырбаев М.К. Марьямев А.Н. Наскальные изображения хребта Каратау. Алматы: Наука, 1977. 232 с.

6. Марьяшев А.Н. Горячев А.А. Наскальные изображения Семиречья. Алматы: ОФ “Родничок”, 2002. $238 \mathrm{c}$.

7. Мотов Ю.А. «Восхождение на небо». К интерпретации погребального обряда пазырыкской элиты по материалам первого кургана могильника Пазырык // ИАС. Сб. ст. и публ. Алматы, 2007. Вып. 3. С. 42-73.

8. Новгородова Э.А. Древняя Монголия (Некоторые проблемы хронологии и этнокультурной истории. М.: Наука, 1989. 383 с.

9. Новоженов B.A. Наскальные изображения повозок Средней и Центральной Азии (к проблеме миграции населения степной Евразии в эпоху энеолита и бронзы). Алматы: Аргументы и Факты - Казахстан, 1994. 266 с.

10. Новоженов B.A. Петроглифы Сары-Арки. Алматы: ИА НАН РК, 2002. 125 с.

11. Рогожсинский A.Е. Тамги Тамгалы // Древности Жетысу. Памятники археологии Жамбылского района. Алматы: Заповедник-музей «Танбалы», 2016. С. 161-173.

12. Рогожинский A.E., Тишин В.В. Древнетюркские рунические надписи и их археологические контексты в горах Кульжабасы // Қазақстан археологиясы. 2018. № 1-2. C. $143-160$.

13. Рябкова Т.В. Изображения ромбовидных знаков как свидетельство миграций в эпоху ранних кочевников // Маргулановские чтения-2011: матер. междунар. конф. (г. Астана, 20-22 апреля 2011 г.). Астана: ЕНУ им. Л.Н. Гумилева, 2011. С. 105-110.

14. Самашев 3., Мургабаев С., Елеуов М. Сауысқандық петроглифтері. Sauyskandyk petroglyphs. Петроглифы Сауыскандыка. Астана: Филиал ИА МОН РК, 2014. 374 с.

15. Семенов Вл.А. Знаки-индексы в наскальном искусстве Северной Евразии // ЮНЕСКО. Междунар. конф. по первобытному искусству: тез. докл. Кемерово: КемГУ, 1998. C. 49-51. 
16. Тэрнер В. Символ и ритуал. Исследования по фольклору и мифологии Востока. М.: Гл. ред. вост. лит-ры, 1983. 277 с.

17. Хужаназаров М. Наскальные изображения Ходжакента и Каракиясая. Самарканд: АН Республики Узбекистан, 1995. $121 \mathrm{c.}$

18. Швец И.Н. Ритуальные сюжеты в наскальном искусстве Центральной Азии // Известия МОН РК. Сер. обществ. наук. 1999. № 1. С. 85-91.

19. Швец И.Н. Ряженый персонаж в наскальном искусстве Центральной Азии (проблемы интерпретации) // Вопросы археологии Казахстана. Алматы; М.: Гылым, 1998. Вып. 2. С. 197-208.

20. Швец И.Н. Сюжеты окуневского изобразительного типа в наскальном искусстве Казахстана // Наскальное искусство в современном обществе (к 290-летию научного открытия Томской писаницы): матер. междунар. науч. конф. Кемерово: КемГУ, 2011. T. 2. C. 134-138.

21. Швец И., Самашев 3., Мургабаев С., Бедельбаева М. Петроглифы местонахождения Саускандык: к проблеме культурных контактов древнего населения Евразии // VII исторические чтения памяти М.П. Грязнова: сб. науч. тр.. Омск: ОмГУ $2008 \mathbf{a}$. C. $342-347$.

22. Швеи И., Самашев 3., Мургабаев С., Бедельбаева М. Некоторые итоги изучения местонахождения петроглифов Саускандык в Южном Казахстане // Вестник КарГУ. Сер. история, философия, право. 2008б. Вып. 4 (52). С. 22-26. $328 \mathrm{c}$.

23. Шер Я.А. Петроглифы Средней и Центральной Азии. М.: Наука, 1980.

24. Assmann J. Das kulturelle Gedächtnis. Schrift, Erinnerung und politische Identität in früheren Hochkulturen. München: C.H. Beck, 2000. 344 s.

25. Bemmann M., König D. Die Felsbildstation Oshibat. Materialien zur Archäologie der Nordgebiete Pakistans 1. Mainz: von Zabern, 1994. 159 S.

26. Fussman G., König D. Die Felsbildstation Shatial. Materialien zur Archäologie der Nordgebiete Pakistans 2: Mainz: von Zabern, 1997. 318 S.

27. Leont'ev N. V. Kapel'ko V. F. Steinstelen der Okunev-Kultur. Archäologie in Eurasien 13. Mainz: von Zabern, 2002. 229 S.

28. Shvets I., Samašev Z., Murgabaev S., Bedelbaeva M. Felsbilder des Karatau-Gebirgsrückens, Südkasachstan. Die Felsbildstation Sauskandyk I-II - Wissenschaftlicher Bericht an die Gerda Henkel Stiftung. Heidelberg: GHS 2008. 320 S.

\section{Сведения об авторе:}

Швец Ирина Николаевна - кандидат исторических наук, доктор археологии Германии (Хайделберг), независимый исследователь, преподаватель археологии в школах для одаренных детей (Германия), основатель педагогического центра «Занимательная археология для детей» (Хайделберг, Германия); schwezi@mail.ru

\section{ОРТАЛЫҚ АЗИЯ ЖАРТАС ӨНЕРІНІН ЖЕЛІСІ КӨШІ- ҚОН ЖОЛДАРЫНЫН БЕЛГІСІ РЕТІНДЕ}

\section{И.Н. Швец}

Мақала біздің тарапымыздан шартты түрде белгі-таңба санатына жатқызылған Орталық Азия жартас өнері желілерінің біріне арналған. Сауысқандық (Оңтүстік Қазақстан) петроглифтеріндегі өгіздердің нақыштары салынған өте бай материалдар тек қана жануарлар денесіндегі әшекейлерді ғана емес, айқын және қисықбедерлі техникада орындалған дөңгелек формадағы белгілердің болуын да көрсетеді. Аталған белгілер ерте қола дәуірінің жартас өнері желілерінің хроноиндикаторы ғана емес, сонымен қатар оңтүстік-батыс бағыттағы Окунево өнерінің дәстүрін жылжыту маркері болып табылады. Петроглифтер мен өрнектер бейнелеу өнерінің ескерткіштері, сонымен қатар iрi ескерткіштер ретінде, бейне мен белгі ретінде, мүмкін иконографиялық кодтарда және «тасқа айналу» арқылы ежелгі адамдардың көші-қон жолы мен байланыстарын белгілеп көрсетуі мүмкін. Сол көші-қондар мен байланыс жолдарын іздеу біздер үшін қашық аймақтардағы ұқсас желістерді анықтауда ғана емес, ортақ белгі-кодтар мен бейнеленгеннің мәнмәтінін анықтауда бұлтартпайтын дәлел болып көрінеді. 
Швец И.Н. Сюжеты наскального искусства Центральной Азии как маркеры...

Түйін сөздер: археология, Орталық Азия, Оңтүстік Қазақстан, Сауысқандық, бейнелеу өнері, петроглифтер, белгі, таңба, код, Окунево мәдениеті, далалық зерттеулер құжаттары

\section{STORIES OF ROCK ART OF CENTRAL ASIA AS MARKERS OF MIGRATION ROUTES}

\section{I.N. Shvets}

The article is devoted to one of the stories of rock art of Central Asia, which we conditionally classified as sign-symbols. Richest material of bull engravings in the petroglyphs of Sauyskandyk (South Kazakhstan) demonstrates not only the diversity of decoration on the body of animals, but also the presence of signs in the form of a circle, made in reliefcounter-relief technique. These signs can not only be identified as chronoindicators of stories of rock art of the era of early bronze, but they are also markers of promotion of traditions of Okunevo art in the south-west direction. Petroglyphs and paintings as monuments of fine art, and even monumental art, can in images and signs and, perhaps in iconographic codes mark and "fossilize" the ways of migration and contacts of ancient people. Finding ways of these migrations and contacts seems more convincing for us not only in determining identical stories in remote territories, but also in identifying common specific sign-codes and contexts of the depicted.

Keywords: archaeology, Central Asia, South Kazakhstan, Sauyskandyk, fine arts, petroglyphs, sign, symbol, code, Okunevo culture, field research documentation

\section{REFERENCES}

1. Baipakov, K. M. Maryashev, A. N. 2004. Petroglify v gorakh Kul'zhabasy (Petroglyphs in the Kulzhabasy Mountains). Almaty: "Print-S" Publ. (in Russian).

2. Beisenov, A. Z., Jumabekova, G. S., Bazarbayeva, G. A., Duysenbay, D. B., Akhiyarov, I. K. 2017. In Arkheolohiya $i$ davnya istoriya Ukrayiny (Archeology and ancient history of Ukraine), 2 (23), 40-58 (in Russian).

3. Devlet, M. A., Devlet, E. G. 2011. Sokrovishcha naskalnogo iskusstva Severnoy $i$ Tsentralnoy Azii (Treasures of rock art of North and Central Asia). Moscow: Institute of Archeology RAS Publ. (in Russian).

4. Esin, Yu. N. 2012. In Nauchnoie obozrenie Saiano Altaya (Scientific Review of Sayano Altay), 1 (3), 14-47 (in Russian).

5. Kadyrbayev, M. K., Maryashev, A. N. 1977. Naskalnyye izobrazheniya khrebta Karatau (Rock paintings of the Karatau ridge). Alma-Ata: „Nauka“ Publ. (in Russian).

6. Maryashev, A. N., Goryachev, A. A. 2002. Naskalnyye izobrazheniya Semirechiya (Rock carvings of the Southwest Kazakhstan). Almaty: „Rodnichok“ Public Foundation Publ. (in Russian).

7. Motov, Ju. A. 2007. In Istoriya i Arkheologiya Semirechiya (History and Archeology of Semirechye), 3, 42-73 (in Russian).

8. Novgorodova, E. A. 1989. Drevnyaya Mongoliya (Nekotoryye problemy khronologii i etnokulturnoy istorii (Ancient Mongolia (Some problems of chronology and ethnocultural history)). Moscow: „Nauka“ Publ. (in Russian).

9. Novozhenov, V. A. 1994. Naskalnyye izobrazheniya povozok Sredney i Tsentralnoy Azii (k probleme migratsii naseleniya stepnoy Yevrazii v epokhu eneolita i bronzy) (Rock carvings of carts of Central and Central Asia (to the problem of migration of the population of steppe Eurasia in the era of Eneolithic and Bronze)). Almaty: Argumenty i Fakty - Kazakhstan Publ. (in Russian).

10. Novozhenov, V. A. 2002. Petroglify Sary-Arki (Petroglyphs of Sary-Arka). Almaty: Institute of Archeology NAS RK (in Russian).

11. Rogozhinskiy, A. Ye. 2016. In Drevnosti Zhetysu (Antiquities Southwest Kazakhstan). Almaty: Museum "Tanbaly", 161-173 (in Russian).

12. Rogozhinskiy, A. Ye., Tishin, V. V. 2018. In Kazakhstan Archeology, 1-2, 143-160 (in Russian) 
13. Ryabkova, T. V. 2011. In Margulanovskie chteniya (Margulan reading-2011). Astana: L.N. Gumilev Eurasian National University Publ., 105-110 (in Russian).

14. Samashev, Z., Murgabayev, S., Eleuov, M. 2014. Petroglyphy Sauyskandyka (Sauyskandyk petroglyphs). Astana: Branch of the A.Kh. Margulan Institute of Archeology Publ. (in Russian).

15. Semenov, Vl. A. 1998. In Mezhdunarodnaya konferentsiya po pervobytnomu iskusstvu (International Conference on Primitive Art). Kemerovo: Kemerovo State University Publ., 49-51 (in Russian).

16. Terner, V. 1983. Simvol i ritual. Issledovaniya po fol'kloru i mifologii Vostoka (Symbol and Ritual. Studies on folklore and mythology of the East). Moscow: Glavnaya redakciya vostochnoi literatury Publ. (in Russian).

17. Khuzhanazarov, M. 1995. Naskalnyye izobrazheniya Khodzhikenta i Karakiyasaya (Rock carvings Khodzhikenta and Karakiyasaya). Samarkand: Academy of Sciences of the Republic of Uzbekistan Publ. (in Russian).

18. Shvets, I. N. 1999. In Izvestiya MON RK (News of the Ministry of Education and Science of the Republic of Kazakhstan), 1, 85-91 (in Russian).

19. Shvets, I. N. 1998. In Voprosy arkheologii Kazakhstana (Issues of Kazakhstan `s archeology), 2. Almaty; Moscow: "Gylym" Publ., 197-208 (in Russian).

20. Shvets, I. N. 2011. In Naskalnoye iskusstvo v sovremennom obshchestve (Rock art in modern society), 2. Kemerovo: Kemerovo State University Publ., 134-138 (in Russian).

21. Shvets, I., Samashev, Z., Murgabayev, S., Bedelbayeva, M. 2008a. In VII istoricheskiye chteniya pamyati M.P. Gryaznova (VII historical readings in memory of M.P. Gryaznov). Omsk: OmSU, 342-347 (in Russian).

22. Shvets, I., Samashev, Z., Murgabayev, S., Bedelbayeva, M. 2008b. In Vestnik KarGU (Bulletin of Karagandy State University), 4 (52), 22-26 (in Russian).

23. Sher, Ya. A.1980. Petroglify Sredney $i$ Tsentralnoy Azii (Petroglyphs of Middle and Central Asia). Moscow: „Nauka“ Publ. (in Russian).

24. Assmann, J. 2000. Das kulturelle Gedächtnis. Schrift, Erinnerung und politische Identität in früheren Hochkulturen. München (in German).

25. Bemmann, M., König, D. 1994. Die Felsbildstation Oshibat. Materialien zur Archäologie der Nordgebiete Pakistans 1. Mainz (in German).

26. Fussman, G., König, D. 1997. Die Felsbildstation Shatial. Materialien zur Archäologie der Nordgebiete Pakistans 2. Mainz (in German).

27. Leontiev, N. V., Kapelko, V. F. 2002. Steinstelen der Okunev-Kultur. Archäologie in Eurasien 13. Mainz (in German).

28. Shvets, I., Samashev, Z., Murgabayev, S., Bedelbayeva, M. 2008. Felsbilder des Karatau-Gebirgsrückens, Südkasachstan. Die Felsbildstation Sauskandyk I-II - Wissenschaftlicher Bericht an die Gerda Henkel Stiftung. Heidelberg (in German).

\section{About the Author:}

Shvets Irina - Candidate of Historical Sciences (Kazakhstan), Dr. Phil. Germany (Heidelberg), Independent researcher, teacher of archeology at schools for gifted children (Germany), founder of the pedagogical center "Living archaeology for children" (Heidelberg, Germany); schwezi@mail.ru

\footnotetext{
Мүдделер қақтығысы туралы ақпаратты ашу. Автор мүдделер қақтығысының жоқтығын мәлімдейді. / Раскрытие информации о конфликте интересов. Автор заявлятт об отсутствии конфликта интересов. / Disclosure of conflict of interest information. The author claim no conflict of interest.

Мақала туралы ақпарат / Информация о статье / Information about the article. Редакцияға түсті / Поступила в редакцию / Entered the editorial office: 07.10.2019. Рецензенттер мақұлдаған / Одобрено рецензентами / Approved by reviewers: 14.10.2019. Жариялауға қабылданды / Принята к публикации / Accepted for publication: 21.10.2019.
} 